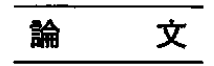

新潟県北蒲原地域胎内川に分布する鮮新統鍬江層の

\author{
珪藻・石灰質ナンノ化石層序 \\ 渡辺 真人*・柳沢 幸夫* $\cdot$ 田中裕一郎** $\cdot$ 山田 桂*** \\ 入月 俊明**** 庄司 真弓*****
}

(Received May 8, 2003 ; accepted September 12, 2003)

\title{
Diatom and calcareous nannofossil biostratigraphy of the Pliocene Kuwae Formation along the Tainai River, Kitakanbara area, Niigata Prefecture, central Japan
}

Mahito Watanabe, Yukio Yanagisawa, Yuichiro Tanaka, Katsura Yamada, Toshiaki Irizuki and Mayumi Shoji

\begin{abstract}
Diatom and calcareous nannofossil biostratigraphy was established for the Pliocene Kuwae Formation along the Natsui stratigraphic section, Tainai River, Kitakanbara area in Niigata Prefecture, central Japan. Three useful diatom biohorizons, the FO (first occurrence) of Neodenticula koizumii, RI (rapid increase) of N. koizumii and LO (last occurrence) of Neodenticula kamtschatica along with calcareous nannofossil datum A defined by Sato and Kameo (1996) were identified in the formation, which established a precise chronologic framework of the Natsui section. Fresh water diatom fossils and reworked Miocene diatom valves occurred throughout the section and the proportion of these taxa fluctuates in a frequency of several tens of thousands years. Sporadic occurrences of warm water diatoms such as Hemidiscus cuneiformis, Nitzschia reinholdii and Rhizosolenia bergonii were recognized at several horizons. Among these, the occurrence at the horizon just above the FO of $N$. koizumii was found both in the present section and in the Yabuta Formation in the Himi area, which suggests its probable correlation.
\end{abstract}

Key words : biostratigraphy, calcareous nannofossil, diatom, Kuwae Formation, Japan Sea, Niigata, Pliocene, Nishiyama Stage

\section{1.はじめに}

本邦の主要な油・ガス田の 1 つである新渇堆積盆には

*産業技術総合研究所地球科学情報研究部門 Institute of Geoscience, Geological Survey of Japan, AIST

** 産業技術総合研究所地球科学情報研究部門 Institute for Marine Resources and Environment, Geological Survey of Japan, AIST

*o*k 金沢大学自然科学研究科 (COE ポストドクトラルフェ -) COE Postodoctoral Fellow, Graduate School of Natural Science and Technology, Kanazawa University

**k** 島根大学総合理工学部地球資䝠塄境学科 Department of Geoscience, Interdisciplinary Faculty of Science and Engineering, Shimane University

**ok** 愛教大付名古屋小 Nagoya elementary school attached Aichi University of education

Copyright (C) 2003, JAPT
第三系および第四系が厚く堆積している。このうち新第 三系の標準層序の 1 つである上部鮮新統の西山階基底 は, 浮遊性有孔虫化石の Globorotalia inflata s. 1. の多 産首準 (No. 3 G. inflata bed；工藤, 1967) 下限によっ て定義されている(米谷, 1978)。この No. 3 G. inflata bed は, 新潟堆積盆の坑井間の対比に有効であるばかり でなく, 日本海側地域の鮮新統の広域対比にあ極めて有 用であることが判明している（たとえば，改訂版「日本 の石油・天然ガス資源」編集委員会，1992）。また， $G$. inflata s. 1. の多産は相対的に温暖な水塊が日本海に流入 したことを示しているとされ，後期鮮新世における日本 海の古環境を復元する上であ重要である（米谷，1988）。

しかし, No. 3 G. inflata bed は, 新湯堆積盆では確 
実な年代層序との直接の対応関係がついておらず，この ためにNo. 3 G. inflata bed の下限で定義される西山階 基底についても十分に信頼できる推定年代が得られてい ない（柳沢ほか，2000）。また，他の微化石層序との関 係も新渴堆積盆では北蒲原地域の陸域セクションで明ら かになりつつあるあのの.(秋元ほか, 1998 ; 平松・三輪 1998)，分析試料の間隔が粗いために詳細な対応関係は まだよく分っていない。

筆者らは，新渇県北蒲原郡黒川村夏井付近の胎内川沿 いの層序セクションに連続露出する鮮新統銭江層を対象 として, No. 3 G. inflata bed の年代を主に珪藻化石と 古地磁気年代層序によって確定すること，およびさまざ まな微化石を用いて後期鮮新世における日本海の古環境 变動を解明することを目的に共同研究を実施している （三輪ほか，2002；山田ほか，2002など）。本論文では, これらの研究の基礎となる珪㩰化石層序と石灰質ナンノ 化石層序の検討結果を報告し, 鈮江層の年代層序を確立 する。

\section{2. 調查地域の層序}

新潟県北部北蒲原地域の櫛形山脈周辺には新第三系が 広く分布し, 下位上り釜杭層, 下関層, 内須川層, 鋮江 層に細彷される（西田・津田, 1961 ; 小林・渡辺, 1985)。調查対象である黒川村夏井付近の胎内川右岸 （夏井セクション；Fig. 1) では, 下関層加ら上位の地 層が露出しており，鈇江層は珪藻質泥岩からなる内須川 首を不整合に覆っている（Fig. 2)。この不整合は大き な時間間隙を伴っており，広域的にみると下位層を大き く侵食する不整合である（平松・三輪，1998）。

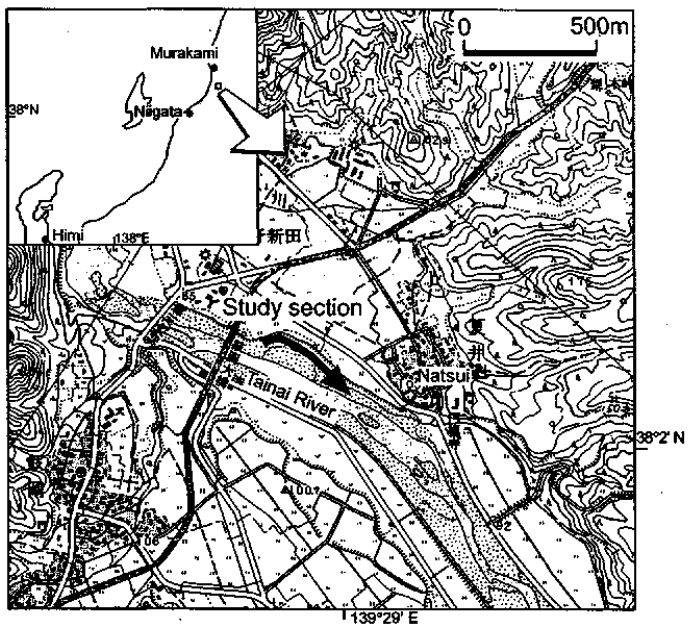

Fig. 1 Location of the Natsui Section (Study section).

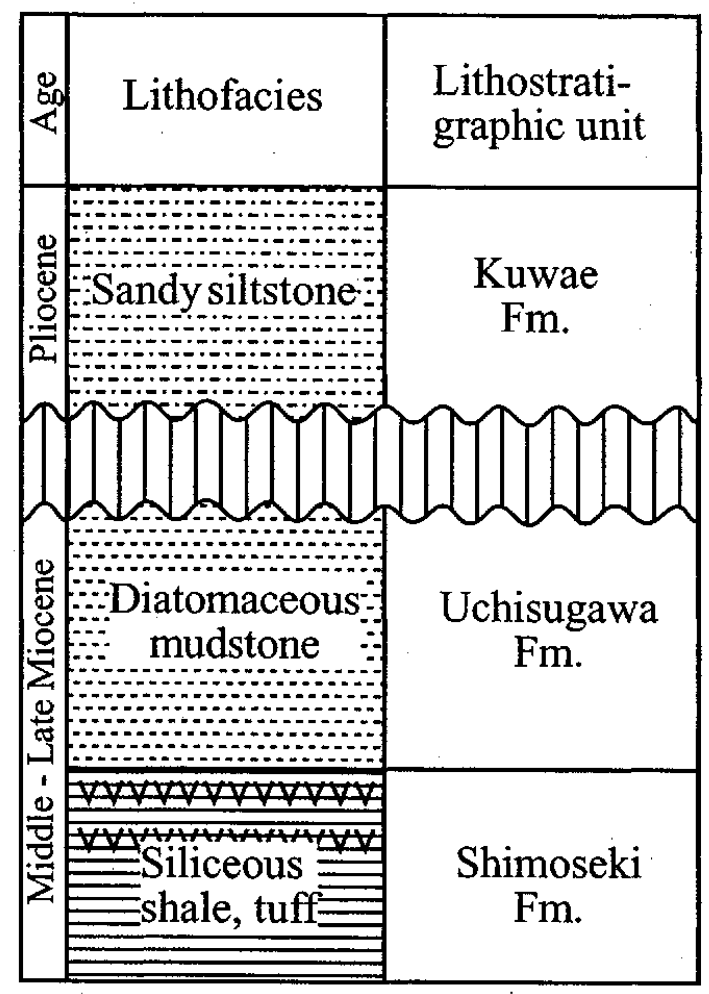

Fig. 2 Schematic column of the Neogene sequence in the study section.

夏井セクションの鐉江層は一部を除きほとんど露頭欠 如がなく, 全層厚は約 $210 \mathrm{~m}$ に達する (Fig. 3)。鎯江層 の下半部は砂岩層ないし砂礫岩層を頻繁に挟在するシル 卜岩ないし砂質シルト岩からなる。一方, 上半部はまれ に砂岩層を挟在するシルト岩ないし砂質シルト岩からな り, 上半部の中では最上部に向かって砂岩層の頻度が增 す (Fig. 3)。砂岩層はしばしば緑色のパミス, 火山ガ ラスを含み, 軟体動物化石片を多量に含むコキナ様の砂 岩層も見られる。このほか, 夏井セクションの鐉江層に は, 胎内川鈇江層ガラス質テフラ層（Tnkg；黒川ほ か, 1999） と胎内川白色テフラ層（Tnkw；黒川ほか, 2003）が挟在する (Fig. 3)。

夏井セクションを含む北蒲原地域のシーケンス層序と 堆積システムを研究した高野ほか. (2001) は, 堆積相之 底生有孔虫群集に基づき, 本セクションの鈋江層の堆積 の場は外側陸棚から斜面であったとし，鉂江層基底と中 部にシーケンス境界があるとした。

\section{3. 分析方法}

この研究では，夏井セクション（Fig. 1）の銊江首の ほぼ全層準にわたって 0.2-0.5 m 間隔で採取した試料か 

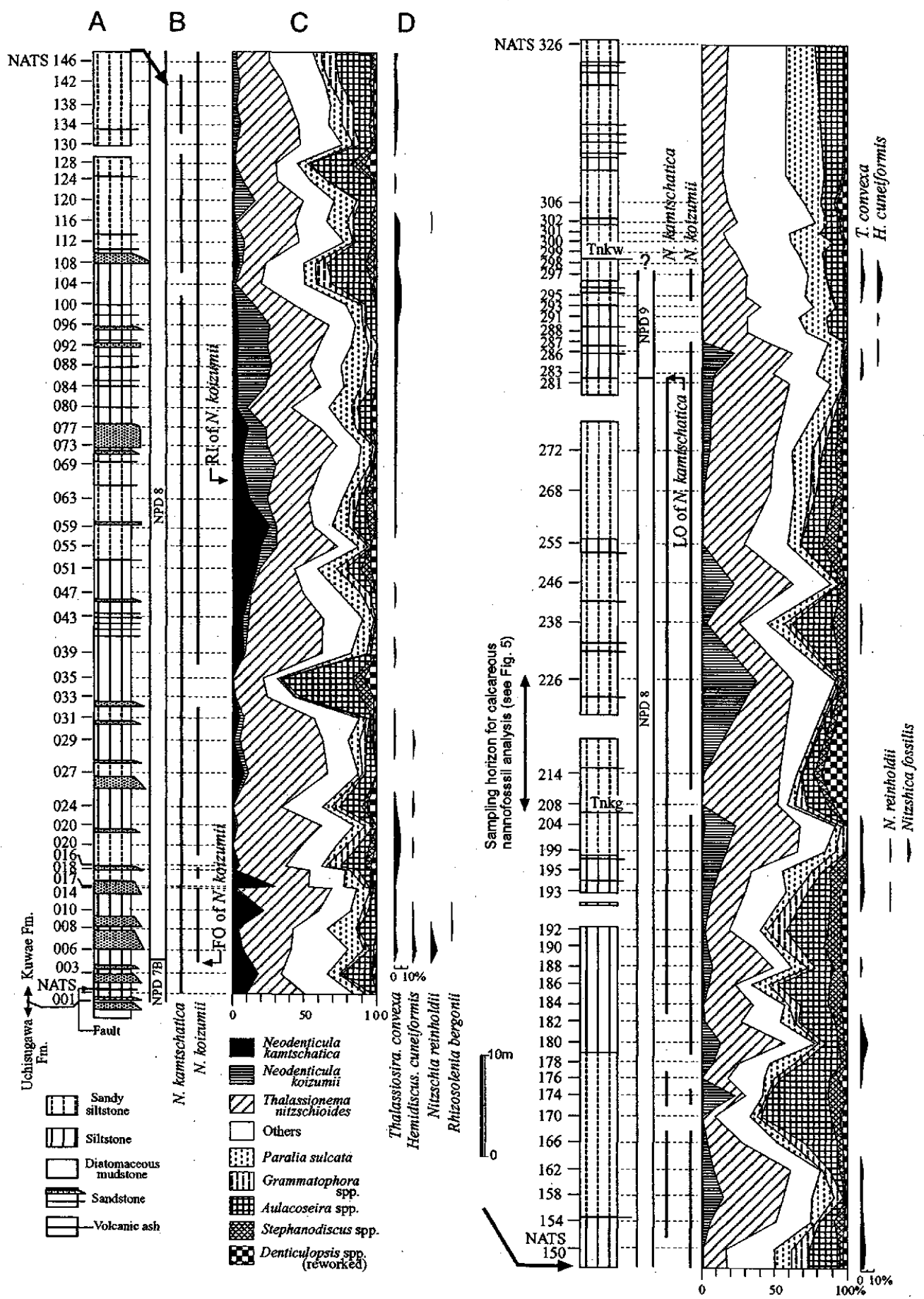

Fig. 3 Stratigraphic distribution of selected diatom species and diatom zones for the Kuwae Formation. A: Lithostratigraphy; B: Diatom zones and stratigraphic occurrence of the marker species Neodenticula kamtschatica and Neodenticula koizumii ; C: Stratigraphic change of the diatom assemblage; D: Stratigraphic occurrence of the warm water species; Tnkg, Tnkw : key tephra layers (after Kurokawa, 2003), FO : first occurrence, RI : rapid increase, LO : last occurrence. 


\section{ら，目的に応じて試料を選び分析した。}

珪㩰化石については, 数 $\mathrm{m}$ 間隔で試料を選び, 合計 89試料について分析を行った。試料は Akiba（1986） の方法で処理し，作成したプレパラートを光学顕微鏡 600 倍と 1,000 倍で検鏡した。任意の湘線に沿って100個 の化石珪藻殼を同定し産出リストを作成し，その後約 500-1,000個の化石珪藻殻を観察して珪藻化石層序に重 要な種の有無を確認した。その結果に基づき, Yanagisawa and Akiba (1998) にしたがって珪㩰化石帯を認 定した。なお，本文中では以下の略号を用いる。FO： 初産出層準, LO : 終産出層準, RI : 急増層準。

石灰質ナンノ化吕については，とくに Sato and Kameo（1996）が定義した datum A (年代2.75 Ma)
を検出するため，珪藻化石層序の結果に基づき $2.7 \mathrm{Ma}$ 前後と推定される層準加ら24試料を採取し，石灰質ナン ノ化石群集の層位変化を分析した。石灰質ナンノ化石分 析武料は, 田中・高橋（1998）と同様な処理を行い， ス ミアスライドを作成し, 光学顕微鏡を用いて1250倍の倍 率で観察を行い，200個の計数・同定を行った。

\section{4. 珪藻化石層序}

検出された主要タクサの産出状況を Fig. 3 に図示し, 産出した珪藻化石の写真を Fig. 4 に示した。夏井セク ションの鉼江層からは, 海生浮遊性種であるNeodenticula kamtschatica, Neodenticula koizumii および Thalassionema nitzschioidesに加えて, 浻岸生ないし
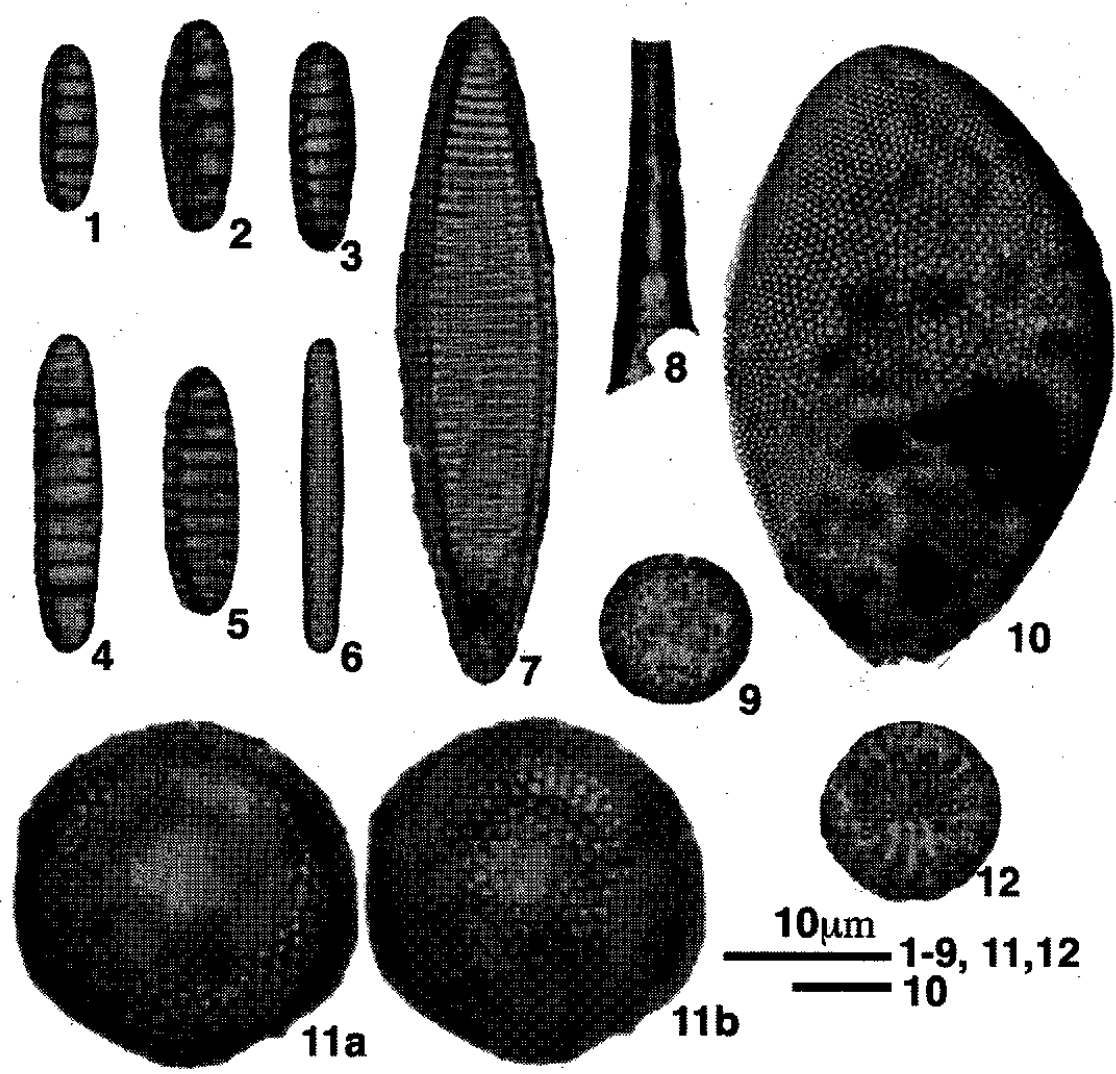

9
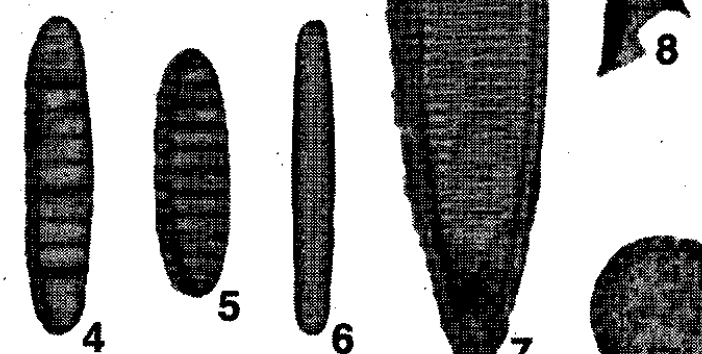

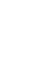


汽水生の Gramatophora spp. や Paralia sulcata, ある いは淡水生の Aulacoseira spp. や Stephanodiscus spp., また中新世に絶滅したDenticulopsis spp，が産出する

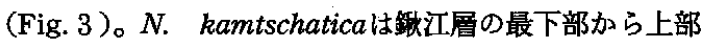
の試料 NATS 226 にかけてほぼ連続的に産出し，特に 下部に産出が多い。N. koizumii は下位から 3 番目の試 料である試料 NATS 006 加ら産出し始め, 試料 NATS 069前後から多産し, 試料 NATS 297 までほぼ連続的に 産出する。ただし，試料. NATS 039 よりる下位では, 産出は断続的で, 頻度もしばしば $1 \%$ \%回る。

N. koizumii の FO (D 80; Yanagisawa and Akiba, 1998 の基準面。以下同様）は武料 NATS 003 と試料 NATS 006 の間にあり，それょりあ下位の層準は， $N$. kamtschatica を産出するがN. koizumii を伴わないので
N. kamtschatica (NPD 7B) にあたる。N. kamtschaticaの LO（D 90）は試料 NATS 281 と試料 NATS 283 の間にあり，試料 NATS 003 から試料 NATS 226 まで の層準は N. koizumii と N. kamtschatica をともに産出 するので, N. koizumii-N. kamtschatica 帯 (NPD 8) にあたる。ただし，鈜江層下部の NATS 016,017，033 および 035 の各試料では，N. kamtschatica が産出する にもかかわらず, N. koizumii が産出しない。この不連 続な産出は, 渡辺 (2002) が論じたように, 日本周辺を 含む北太平洋中緯度域では，N． koizumiiの FO (D 80) 直上付近では同種の産出がまれであることによると考え られる。

渡刀 (2002) はN. koizumii の RI が有用な生層準と なる可能性を指摘したが, 本研究では試料採取間隔が相

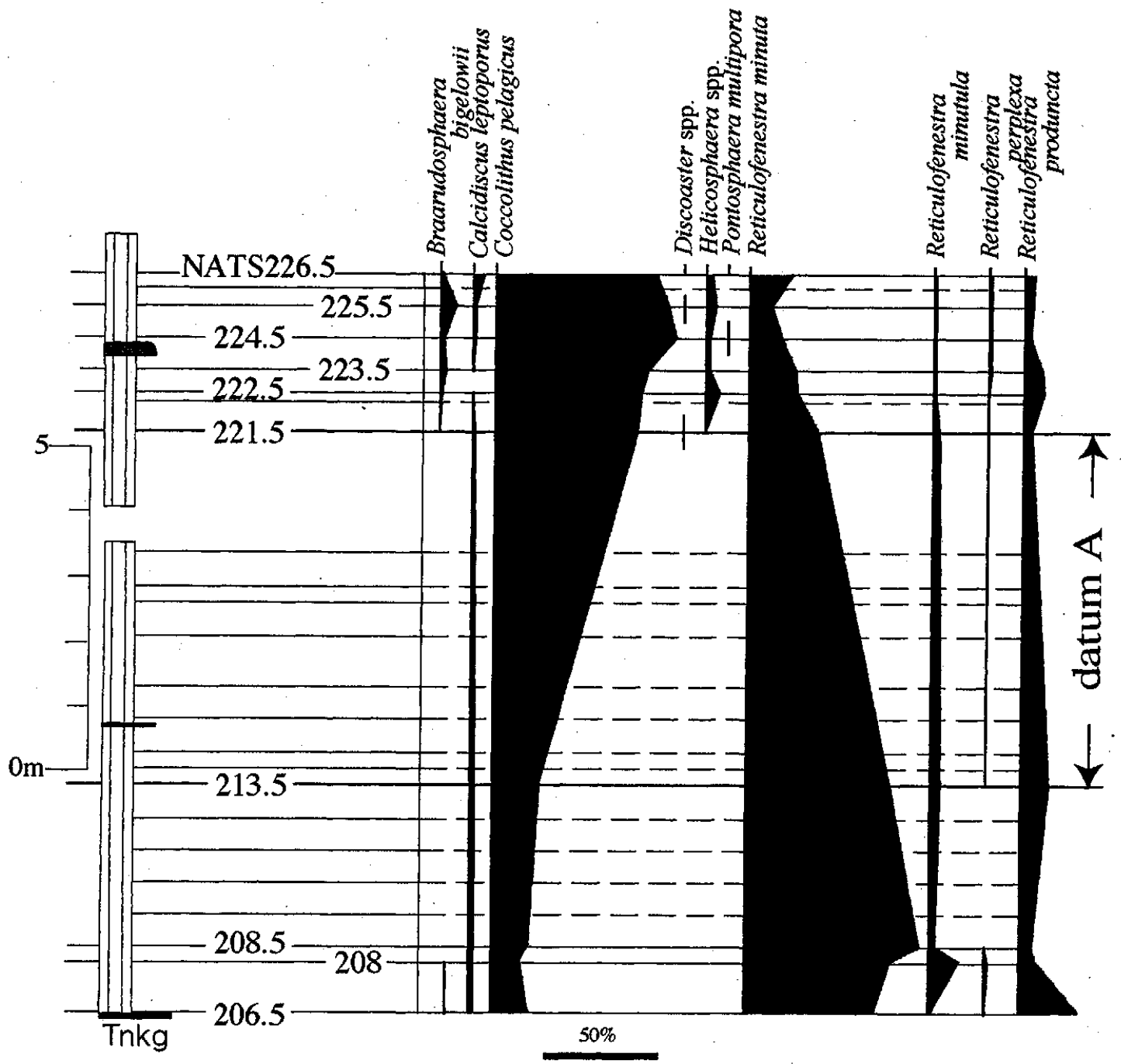

Fig. 5 Stratigraphic change of the calcareous nannofossil assemblage. 
対的に密であるため，同種の明瞭な急増は認められな い。ただし，N. kamtschatica とN. koizumii の頻度を 比べると, 試料 NATS 063から下位の層準では前者の方 が大きく，試料 NATS 069から上位の層準では後者の方 が大きく,陚料 NATS 063 と試料 NATS 069 の間で頻度 の逆転が認められる。したがって, 試料 NATS 063 と 試料 NATS 069 の間にN．koizumii の RI を認めること ができる。このことから，本研究のように試料間隔が密 である場合，N. koizumiiの RI は，同種と N. kamtschatica の頻度の逆転をむって認定するのが実用的と 考えられる。

N. koizumii は試料 NATS 298 より上位では産出しな いが, それらの層準では珪藻化石の保存が悪く, 非海生 の珪藻化石の割合が高くなっていることから；試料 NATS 298 の層準は見かけの N. koizumii の終産出層準 であると考えられる。これについては考察で議論する。

\section{5. 石灰質ナンノ化石層序}

24試料のうち, Coccolithus pelagicus, small Reticulofenestra spp. (=Reticulofenestra minuta) と small Dictyococcites'spp. (=Reticulofenestra producta) は, 10 試料から産出が認められた（Fig. 5)。.Sato and Kameo（1996）が定義した datum A (2.75 Ma).は, small Reticulofenestra spp. $と$ small Dictyococcites spp. の両タクサの多産から C. pelagicus の多産への産出頻度 の急激な変化を示す基準面である。錸江層において，こ れら 3 タクサのうち, 前者の 2 夕クサの産出頻度の合計 は, 試料 NATS 206.5から試料 NATS 208.5 にかけて の層準で $75 \%$ 以上を, 試料 NATS 213.5 で58\%を占め るのに対し，武料 NATS 221.5 では $25 \%$ と低くなる。逆 に, この層準加上位では, C. pelagicus の産出頻度が $75 \%$ 以上を占める。石灰質ナン人化石の産出頻度を分析 した最上位層準の試料 NATS 226.5 より上位の試料 NATS 281には，上述したように2.6-2.7 Ma の年代を 示す N. kamtschatica の最終産出が認められているこ と, 同じと，分析した最下位層準の試料 NATS 206.5 より下位の試料 NATS 063 之試料 NATS 069 の間に $N$. koizumii のRI (3.0-3.1 Ma) 加認加られるこ加ら, 石灰質ナンノ化石の small Reticulofenestra spp. (= Reticulofenestra minuta) $と$ small Dictyococcites spp. (=Reticulofenestra producta) の両夕クサの多産から C. pelagicus 多産へ転換する層準，すなわち試料 NATS 213.5 と試料 NATS 221.5 の間が datum A に相当する と判断できる。

石灰質ナンノ化石の基準面 datum A は, 北陸富山県 水見地域の薮田層（高山ら，1988）や, 秋田県の笹岡層
（佐藤ら，1999）でも認められている。今回調查した䤨 江首でも datum A が認められたことは，佐藤ら (1999，2003）肪指摘しているょうに,"ここの生層準が日 本海側一帯の上部鮮新統に特徽的に見いだせることを追 認したことになる。

\section{6. 考 察}

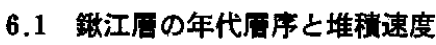

夏井セクションの錐江層では年代決定有効な生層準 として, 珪藻化石の Neodenticula koizumii の FO (D $80,3.5 \mathrm{Ma})$ と N. koizumii の RI (3:1-3.0Ma) および Neodenticula kamtschatica の LO (D90, 2.7-2.6Ma), また石灰質ナンノ化石層序の datum A (2.75 Ma) が 確認された。さらに，黒川ほか（2003）は，陚料 NATS 298 と299の間に挟在する胎内川白色テフラ層 （Tnkw）を，新渴中央油帯の西山層中の田沢白色ガラ ス質テフラ層 (Tzw) に対比し, 上下の広域テフラ層 の年代から，その年代を約 $2.6 \mathrm{Ma}$ と推定している。

これらの生層準とテフラ層の年代をむとに求めた夏井 セク.ションの堆積速度を Fig. 6 に示す。N. koizumii の RI より下位の首準では, 堆積速度はおよそ $9-13 \mathrm{~cm} / \mathrm{k}$. y.である。これに比べて, それより上位の層準では堆 積速度が約 $25-44 \mathrm{~cm} / \mathrm{k} . y$. と速くなっている。

なお，前述のように $N$. koizumii の LO (D 100，2.0 Ma) は，試料 NATS 297.と298の間に認められたが，そ の直上に挟在する胎内川白色テフラ層 (Tnkw) の年代 が約 $2.6 \mathrm{Ma}$ と推定されること（黒川，2003）, 前節で 述べたように試料 NATS 298よりも上位の層準において 珪藻化石の保存が悪く海生種の割合が極端に下がること を考慮すると，武料 NATS 298から上位でN. koizumii が産出しないのは, 環境的な原因や珪藻凯の選択的な溶 解が原因であると考えられる。また，本セクションの鉂 江層最上部の古地磁気層序によれば，本セクションの最 上部恬 Matuyama Chronozone 最下部に当たり, $N$. koizumii の LO (D 100) の層準 (2.0 Ma) よりは下位 であることが明らかとなっており（井上ほか，2003）, このことあ試料 NATS 297 と298の間にあるN. koizumii の LO が真の LO ではないという判断を支持する。

同一試料を使って行われた浮遊性有孔虫化石の検討結 果 (三輪ほか, 2002) では, No. 3 G. inflata bed の基 底は N. koizumii の FO の約 $10 \mathrm{~m}$ 上位にあり, N. koizumii-N. kamtschatica 帯（NPD 8）下部にあたる。一方, 氷見地域ではNo. 3 G. inflata bed の基底は NPD 8 上部 に位置づけられており（渡边, 2002), 本セクションに おける結果と若干の食い違いが認的られる。この問題に ついては, 今後の課題である。 


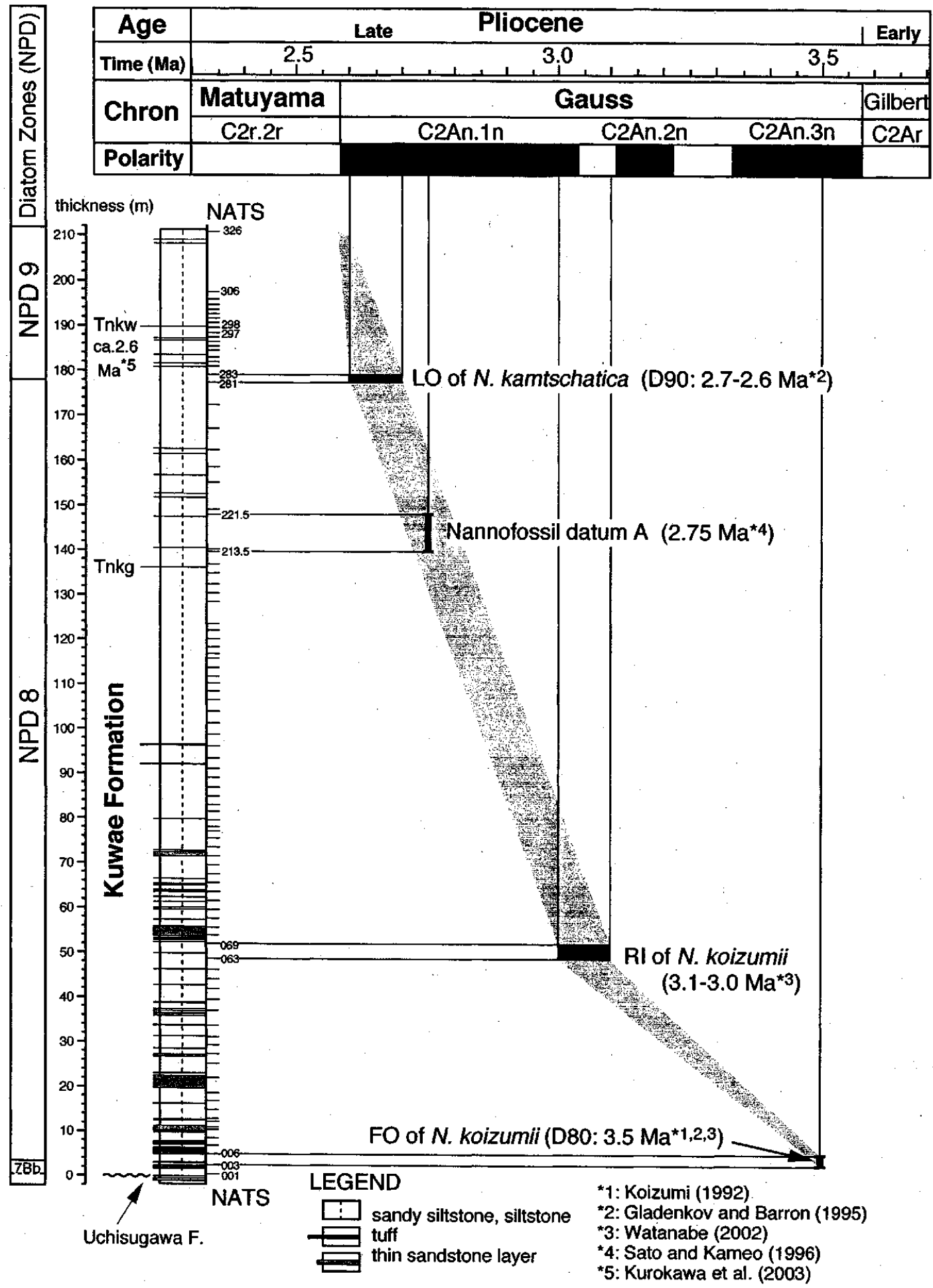

Fig. 6 Sediment accumulation curve for the Kuwae Formation. Magnetostratigraphic scale after Berggren et al. (1995). FO : first occurrence, RI : rapid increase, LO : last occurrence. 


\section{2 鐴江厚の堆程環境}

前述したように, 調查セクションの鉂江層からは, 層 準によっては淡水生の珪藻化石を多産する。また, 中新 世に絶滅したDenticulopsis spp. が鉄江層からはほぼ連 続的に産出するが, 鋷江層の堆積年代は鲜新世であるこ とから，それらは中新統が削剥されることによりあたら された再堆積化石であると判断できる。

淡水生の Aulacoseira spp. と Stephanodiscus spp. 打 よび再堆積化石であるDenticulopsis spp. の頻度はほぼ 同調して変動している (Fig. 3)。これらは, 河川によ り陸域から運搬され調查地域に堆積したあのであるの で, その産出頻度は, 堆積時の河川による研屑物の供給 量の变動と関係が深いと考えられる。両者の産出頻度 は, 層厚にして 5-15 m 程度の間隔でピークを作ること 加ら，数万年程度の周期で変動していたと推定される。 鮮新世の酸素同位体比の变動は約41000年を卓越周期と しており (Schackleton et al., 1995), この珪藻化石群 集の変動はそれと連動している可能性がある。これに関 しては, ほかの化石の群集組成の変動を考慮に入れてさ らに検討を進める予定である。

また, Fig. 3 に外洋性温暖種 4 種の産出状況を示した が, Thalassiosira convexa は過半数の試料から産出す るのに対し, Hemidiscus cuneiformis, Nitzschia reinholdii およびRhizosolenia bergonii は産出する層準が 限られている。このうち，N. koizumii の FO 直上に 4 種がそろって産出する現象は, 氷見地域の薮田首であ観 察されており（渡辺，2002）, 当時の日本海の広域的な 古海洋環境の変化（温暖化）をとらえている可能性が高 い。しかし, 温暖種の産出頻度が小さいために今回の分 析方法ではその頻度変化を詳細にとらえることができな かった。今後は海成種のみをカウントして温暖種の割合 を求めることにより, 本セクションの試料を用いて鲜新 世の日本海における対馬海流の消長に関する重要な情報 が得られるであろう。

ところで，高野ほか（2001）は夏井セクションの鎯江 層を二つの堆積シーケンスに分け、錐江層基底と鍁江首 中部にシーケンス境界を置いた。しかし, 今回の珪藻化 石の分析結果吕らは, 上記の数万年程度の周期の変動が 見られるのみで, さらに周期の長い変動は明らかではな い。この問題に関しても, 今後の検討課題である。

\section{7. まとめ}

この研究では, 新潟県北蒲原郡黒川村の夏井セクショ ンにおける上部鮮新統䤨江層の珪藻化石層序を検討し た。その結果，以下のことが明らかになった。

1. 鐉江層では年代決定有効な生層準として, 珪藻化
石の Neodenticula koizumii の FO (D 80, 3.5 Ma) と N. koizumii の RI (3.1-3.0 Ma) および Neodenticula kamtschatica の LO (D 90, 2.7-2.6 $\mathrm{Ma})$ ，石灰質ナンノ化石層序の datum A (2.75 Ma) が確認され, 珪藻化石帯としてN. kamtschatica 帯 (NPD 7 B), N. koizumii-N. kamtschatica 帯 (NPD 8), N. koizumii 帯（NPD 9) が認められた。今回 鉔江層の年代層序が確立したことにより, 今後浮遊 性有孔虫の No. 3 Globolotalia inflata bedの年代と その古環境的な意義を杽論する基盤ができた。

2. 他地域と同様に，鉃江層で屯 N. koizumii の急減 層準 (RI) が, 同種と N. kamtschatica の頻度の逆 転層準として認識され，この生層準の有用性が確認 された。

3. 鍁江層の珪藻化石群集では, 淡水生および再堆積 性の珪㩰化石の産出頻度が数万年前後の周期で変動 していること，また N. koizumii の初産出層準 (FO) 直上付近で温暖珪藻種が産出する層準が鍛江 層之永見地域の像田層で共通に認められることが明 らかとなり, 鍁江層の珪藻化石群集はさまざまな古 環境变動を記録していることが分かった。

\section{謝 辞}

筑波大学本山 功博士, 同大学院井上博文氏および愛 知教育大学の星 博幸博士には野外における試料採取を 手伝っていただいた。産業技術総合研究所地球科学情報 研究部門の高橋雅紀博士には古地磁気首序について, 石 油資源開発株式会社技術研究所三輪美智子研究員には浮 遊性有孔虫化石層序について，それぞれご助言をいただ， いた。黒川村の坂上源助氏には，夏井セクションにおけ， る試料採取を快く了承していただいた。本研究で検鏡し た珪藻および石灰質ナンノ化石用のスライドは, 産業技 術総合研究所地球科学情報研究部門の平井圭子職員に

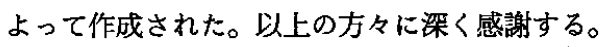

\section{文 献}

Akiba, F., 1986: Middle Miocene to Quaternary diatom biostratigraphy in the Nankai Trough and Japan Trench, and modified Lower Miocene through Quaternary diatom zones for middle-to-high latitudes of the North Pacific. In Kagami, H., Karig, D. E., Coulbourn, W. T. et al. eds., Init. Repts. DSDP, 87, U.S. Govt. Printing office, Washington, D. C., $393-480$.

秋元和實 - 平野義明 - 小林孷雄 - 渡辺其久男, 1998 ：新 潟油田地域東縁, 笹神丘陵の鮮新統安野川層の年代之 古環境. 地球科学, 52, 486-497.

Barron, J. A. and Gladenkov, A, 1995 : Early Miocene 
to Pleistocene diatom stratigraphy of Leg 145 . In Rea, D. K., Basov, I. A., Scholl, D. W., and Allan, J. F. eds., Proc. ODP, Sci. Results, 145, College Station, TX (Ocean Drilling Program), 3-19.

Berggren, W. A., Hilgen, F. J., Langereis, C. G., Kent, D. V., Obradovich, J. D., Raffi, I., Raymo, M. E. and Shackleton, N. J., 1995 : Late Neogene chronology : New perspectives in high-resolution stratigraphy. Bull. Geol. Soc. Amer., 107, 1272-1287.

平松 力 -三輪美智子, 1998 : 新潟県北蒲原地域の新第 三系微化石層序と鍜江層基底の不整合形態. 石技誌, 63, 301-314.

井上博文・山田 桂・高橋雅紀・本山 功 - 楖沢幸夫, 2003：新潟県北蒲原地域の胎内川におりる鮮新統鉜江 層最上部の古地磁気層序. 石技誌, 68, 570-580.

改訂版「日本の石油・天然ガス資源」編集委員会編, 1992 : 改訂版日本の石油・天然ガス資源，天然ガス鉱 業界・大陸棚石油開発協会, 520 p.

小林㦑雄・渡辺其久男, 1985 ：新潟油田東縁帯における 新第三紀の地史的事件一とくに, 中新一鮮新世の不整 合について一，新潟大理学部地鉱研究報告, 5, 91103.

Koizumi, I., 1992: Diatom biostratigraphy of the Japan Sea: Leg 127. In Pisciotto, K. A., Ingle, J: C., jr., von Breymann, M. T. and Barron, J. et al., Proc. ODP, Sci. Results, 127/128, Pt. 1, College Station, TX (Ocean Drilling Program), 249-289.

工藤哲朗, $1967 ：$ 新潟ベーズンにおける Foraminiferal Ratioの利用について。第32回石技協定時総会個人講 演要旨集, 13-14.

黒川勝己・永田 亮・吉田卓司, 1999 : 新発田市上荒沢 ～黒川村胎内川地域の内須川層 - 銭江層の火山灰一之 くに錐江層中の Znp-Ywg 相当火山灰層について一. 新潟大学教育人間科学部紀要, 2, 1-32.

黒川勝己・桶口裕也・平中宏典, 2003 ：西山層中部の Tzw テフラ層とその対比。平成12年度〜平成14年度 科学研究費補助金（基盤研究 $(\mathrm{C})(2)$ ) 研究成果報告書, 広域テフラによる日本列島中新統〜下部更新統の精密 対比, 317-322.

米谷盛壽郎, 1978 : 東北日本油田地域におりる上部新生 界の浮遊性有孔虫層序。日本の新生代地質（池辺展生 教授記念論文集)，35-60.

米谷盛壽郎, 1988 : 有孔虫化石群の変遷に見られる新第 三紀イベント。新第三紀における生物の進化・変要之 それに関するイベント，IGCP-246・日本古生物学会 1987年年会シンポジゥム (静岡) 特集号別刷, 大阪市 立自然史博物館, $31-48$.

西田彰一・津田禾粒, 1961 : 新渴県坂町付近の新第三 系. 槙山次郎教授記念論文集, 107-113.

三輪美智子 - 山田 桂 - 入月俊明 - 田中裕一郎 - 庄司真
弓・渡包真人・柳沢幸夫, 2002 : 新潟県胎内川の鮮新 統鍁江層の浮遊性有孔虫化石群集 (予報) 一とくに No. 3 Globorotalila inflata bed について一. 日本古 生物学会 2002 年年会予稿集, 94 .

Sato, T., and Kameo, K., 1996 : Calcareous nannofossil biostratigraphy of the Arctic Ocean., ODP Leg 151. In Thiede, J., Myhre, A. M., Firth, J. V., Johnson, G. L. and Ruddiman, W. F. eds., Proc. ODP Sci. Results, 151,College Station, TX (Ocean Drilling Program), 39-59.

佐藤時幸・亀尾浩司 ·三田 熟, 1999 ：石灰質ナンノ化 石による後期新生代地質年代の決定精度とテフラ層 序。地球科学, 53, 265-274.

佐藤時幸 - 樋口武志 - 石井崇暁 - 湯口志穗 - 天野和孝 龟尾浩司, 2003: 秋田県北部に分布する上部鮮新統〜 最下部更新統の石灰質ナンノ化石層序一後期鮮新世古 海洋変動と関連して一。地質雑, 109, 280-292.

Shackleton, N., Hall, M. and Pate, D., 1995: Pliocene stable isotope stratigraphy of Site 846. In Pisias, N. G., Mayer, L. A., Janecek, T. R., Palmer-Julson, A. and Andel, T.H. eds., Proc. ODP Sci. Results, 138, College Station, TX (Ocean Drilling Program), 337 -355 .

高野 修·守屋成博 - 西村瑞恵 - 秋葉文雄 - 阿部正憲 · 楖本 裕, 2001 : 新潟堆積盆北蒲原地域におりる上部 中新統〜下部更新統のシーケンス層序と堆積システム の特徵. 地質雑, 107, 585-604.

高山俊昭 - 加藤道雄 - 工藤哲朗 - 佐藤時幸 - 亀尾浩司, 1988 : 日本海側に発達する最上部新生界の石灰質微化 石層序, その 2：北陸堆積盆地．石技誌，52, 231242.

田中㭲一郎 - 高橋雅紀, 1998 : 枋木県鳥山地域に分布す る中新統荒川層群下部の石兏質ナンノ化石首序, 地質 雑, 104, 779-793.

湾辺真人, 2002 : 富山県水見 - 灘浦地域の鮮新統の珪藻 化石層序と年代層序の再検討一之くに広域火山灰首之 No. 3 Globorotalila inflata (浮遊性有孔虫) bedの年 代について一，地賀雑，108，499-509.

山田 桂 - 渡辺真人 - 田中裕一郎 - 三輪美智子 - 楖沢幸 夫 ·入月俊明, $2002 ： 2.80-2.55 \mathrm{Ma}$ における日本海 海成層一新潟県䥃江首の例一: 日本古生物学会2002年 年会予稿集, 102 .

Yanagisawa, Y. and Akiba, F., 1998, Refined Neogene diatom biostratigraphy for the northwest Pacific around Japan, with an introduction of code numbers for selected diatom biohorizons. Jour. Geol. Soc. Japan, 104, 395-414.

柳沢幸夫 ·渡辺其久男 - 小林政雄, 2000：標準層序（階 区分). 新潟県地質図改訂委員会編, 新潟県地質図説 明書（2000年版）, 31-34. 